\title{
PELATIHAN PERWUJUDAN KELUARGA SAKINAH MELALUI PENGELOLAAN KEUANGAN RUMAH TANGGA SECARA SYARIAH DI DESA BATU RT/RW :1/1 KECAMATAN KARANG TENGAH KABUPATEN DEMAK
}

\author{
Sri Retnoningsih ${ }^{1}$, Risti Lia Sari ${ }^{2 *}$ \\ ${ }^{1}$ Jurusan Akuntansi, Fakultas Ekonomi, Universitas Wahid Hasyim \\ Jl. Menoreh Tengah X/22, Sampangan, Semarang 50236 \\ ${ }^{2}$ Program Studi Ekonomi Islam, Fakultas Ekonomi, Universitas Wahid Hasyim \\ Jl. Menoreh Tengah X/22, Sampangan, Semarang 50236 \\ *Email : ristiliasari@gmail.com
}

\begin{abstract}
Kegiatan pengabdian masyarakat dalam bentuk pelatihan perwujudan keluarga sakinah yang bertujuan mengatur manajemen keuangan rumah tangga syariah, dapat mengelola keuangan dengan baik, meningkatkan pengetahuan manajemen keuangan rumah syariah, untuk mengetahui manajemen keuangan syari'ah dalam mewujudkan keluarga bahagia. Kegiatan pengabdian masyarakat diawali dengan persiapan pelaksanaan kegiatan, yaitu persiapan tim dengan melakukan rapat koordinasi, membuat surat undangan, membagikan undangan kepada ibu-ibu komunitas Desa Rt / Rw: 1/1 Kabupaten Batu Karang Tengah, Kabupaten Demak.Kegiatan persiapan meliputi penyelenggaraan kuliah dan diskusi, yaitu Mushala Baitul Muhsinin, menyediakan media presentasi, yaitu slide presentasi dan Infocus / LCD 3. Membuat modul yang akan digunakan dalam perkuliahan dan diskusi. Modul ini dibuat oleh pembicara dengan cakupan dalam bentuk materi yang akan diberikan dalam ceramah dan wacana. Modul ini dibuat dalam bentuk tutorial, teori dan contoh-contoh manajemen keuangan rumah tangga syariah. Dalam kegiatan kuliah dan diskusi, ada dua penyaji yang memberikan penjelasan tentang pengelolaan keuangan rumah tangga syariah. Materi berupa penjelasan tentang konsep keluarga sakinah, bagaimana membentuk keluarga sakinah, pengelolaan keuangan rumah tangga syari'ah sebagai manifestasi keluarga sakinah dan masalah-masalah yang sering dihadapi oleh beberapa rumah tangga sehingga perlu memiliki manajemen keuangan syariah
\end{abstract}

Kata Kunci: Pengelolaan Keuangan, Keluarga Sakinah

\section{PENDAHULUAN}

Harta di dalam Islam merupakan amanah atau titipan dan hak milik seseorang. Kewenangan untuk memanfaatkannya terkait erat dengan adanya kemampuan (kompetensi) dan kepantasan (integritas) dalam mengelola aset atau dalam istilah prinsip kehati-hatian perbankan (prudential principle). Prinsip di dalam Islam mengajarkan bahwa "Sebaik-baik harta yang shalih (baik) adalah dikelola oleh orang yang berkepribadian shalih (orang yang amanah dan orang yang profesional)." Hak bekerja dalam arti kebebasan untuk melakukan berusaha, berdagang, memproduksi barang maupun jasa untuk mencari rezki Allah secara halal merupakan hak setiap manusia tanpa diskriminasi antara laki dan perempuan. Bila kita mengetahui bahwa kaum hawa diberikan oleh Allah hak milik dan kebebasan untuk memiliki, maka sudah semestinya mereka juga memiliki hak untuk berusaha dan mencari rezki di muka bumi ini.

Rasulullah shallallahu 'alaihi wa sallam memuji seseorang yang mengkonsumsi hasil usahanya sendiri dengan sabdanya: "Tidaklah seseorang mengkonsumsi makanan lebih baik dari mengkonsumsi makanan yang diperoleh dari hasil kerja sendiri, sebab nabi Allah, Daud, memakan makanan dari hasilkerjanya." (HR. Bukhari). "Semoga Allah merahmati seseorang yang mencari penghasilan secara baik, membelanjakan harta secara hemat dan menyisihkan tabungan sebagai persediaan di saat kekurangan dan kebutuhannya." (HR. Muttafaq 'Alaih). Hal ini menunjukkan bahwa Islam menghendaki setiap muslim untuk dapat mengelola usaha dan berusaha secara baik, mengelola dan memenaj harta secara ekonomis, efisien dan proporsional serta memiliki semangat dan kebiasaan menabungatau menginvestasikan sebagian hartanya untuk masa depan dan persediaan kebutuhan mendatang. Prinsip ini sebenarnya menjadi dasar ibadah kepada Allah agar dapat diterima (mabrur) karena saran, niat dan caranya yang baik. Rasulullah shallallahu 'alaihi wa 
sallam bersabda: "Sesungguhnya Allah itu baik dan hanya menerima yang baik-baik saja." (HR. Muslim).

Kesadaran akuntabilitas (ma'uliyah) dalam bidang keuangan itu yang mencakup aspek manajemen pendapatan dan pengeluaran timbul karena keyakinan adanya kepastian audit dan pengawasan dari Allah subhanahu wa ta'ala seperti sabda Nabi shallallahu 'alaihi wa sallam: "Kedua telapak kaki seorang hamba tidak akan beranjak dari tempat kebangkitannya di hari kiamat sebelum ia ditanya tentang empat hal, di antaranya tentang hartanya; dari mana dia memperoleh dan bagaimana ia membelanjakan." (HR. Tirmidzi) Dari penjelasan di atas dapat diungkapkan beberapa masalah yang umumnya dihadapi oleh pihak mitra terkait dengan pengelolaan keuangan rumah tangga secara syari 'ah, yaitu tidak menetapkan skala prioritas keuangan rumah tangga, tidak seimbangnya pendapatan dan pengeluaran, pengeluaran yang tidak terencana dengan baik, tidak mencatat dan mengatur cashflow keuangan rumah tangga

\section{METODE}

Tempat dan Waktu Kegiatan pengabdian masyarakat tentang pelatihan perwujudan keluarga sakinah melalui pengelolaan keuangan rumah tangga secara syari ah di Desa Batu $\mathrm{Rt} / \mathrm{Rw}$ : 1/1 Kecamatan Karang Tengah Kabupaten Demak pada hari Sabtu tanggal 5 Mei 2018. Objek yang menjadi sasaran dari kegiatan pengabdian ini adalah mayarakat warga Desa Batu $\mathrm{Rt} / \mathrm{Rw}$ : 1/1 Kecamatan Karang Tengah Kabupaten Demak. Mereka yang menjadisasaran ibu-ibu rumah tangga sebagai pihak yang bertanggungjawab terhadappengelolaan keuangan keuangan rumah tangga, Kegiatan pengabdian ini dilakukan dengan menggunakan pendekatan ceramah dan diskusi kepada Karang Tengah Kabupaten Demak warga Desa Batu Rt/Rw : 1/1 Kecamatan Karang Tengah Kabupaten Demak tentang pelatihan perwujudan keluarga sakinah melalui pengelolaan keuangan rumah tangga secara syari`ah.

Adapun langkah-langkah yang dilakukan yaitu dengan tahap meningkatkan pengetahuan pengelolaan keuangan rumah secara syari ah, dan tahap pengelolaan keuangan secara syari ah dalam mewujudkan keluarga sakinah. Pelaksanaan Kegiatan pengabdian masyarakat ini diawali dengan persiapan pelaksaan kegiatan, yaitu persiapan tim dengan melakukan rapat koordinasi, pembuatan surat undangan, penyebaran undangan kepada ibu-ibu masyarakat warga Desa Rt/Rw : 1/1 Batu Kecamatan Karang Tengah Kabupaten Demak. Kegiatan selanjutnya adalah persiapan kelengkapan kegiatan yang meliputi hal-hal sebagai berikut:

1. Mempersiapkan tempat pelaksanaan ceramah dan diskusi, yaitu Mushala Baitul Muhsinin.

2. Mempersipkan media presentasi, yaitu slide presentasi dan Infocus/LCD

3. Pembuatan modul yang akan digunakan dalam ceramah dan diskusi.

Modul tersebut dibuat oleh pemateri dengan cakupan berupa materi-materi yang akan diberikan dalam ceramah dan diskusi. Modul tersebut dibuat dalam bentuk tutorial, teori dan contoh pengelolaan keuangan rumah tangga secara syari'ah. Dalam kegiatan ceramah dan diskusi tersebut, ada dua orang pemateri yang memberikan penjelasan tentang pengelolaan keuangan rumah tangga secara syari 'ah. Materi berupa penjelasan tentang konsep keluarga sakinah, bagaimana membentuk keluarga sakinah, pengelolaan keuangan rumah tangga secara syari ah sebagai perwujudan keluarga sakinah serta permasalahan-permasalahan yang selama ini sering dihadapi oleh sebagian rumah tangga sehingga perlu adanya pengelolaan keuangan secara syari`ah.

\section{HASIL DAN PEMBAHASAN}

Dari penjelasan di atas dapat diungkapkan beberapa masalah yang umumnya dihadapi oleh pihak mitra terkait dengan pengelolaan keuangan rumah tangga secara syari ah, yaitu:

1. Tidak menetapkan skala prioritas keuangan rumah tangga

2. Tidak seimbangnya pendapatan dan pengeluaran

3. Pengeluaran yang tidak terencana dengan baik

4. Tidak mencatat dan mengatur cashflow keuangan rumah tangga.

Dengan adanya diberikan pelatihan tentang pelatihan pengelolaan keuangan rumah tangga yang syariah diharapkan masyarakat warga Desa Batu Kecamatan Karang Tengah dapat tercipta keluarga yang sakinah dan kegiatan pengabdian ini bertujuan untuk:

1. meningkatkan kesadaran masyarakat tentang pentingnya menentukan skala proritas dalam pengelolaan keuangan rumah tangga secara syari ah 
2. memberikan pemahaman tentang pentingnya menjaga keseimbangan antara pemasukan dan pengeluaran rumah tangga secara syari ah

3. memberikan pengetahuan tentang perlu perencanaan yang matang setiap pengeluaran

a. baik yang rutin seperti belanja bebutuhan rumah tangga sehari-hari dan pengeluran non rutin seperti pembelian peralatan rumah tangga, liburan dan lain-lain, dan

4. memberikan pelatihan tentang pencatatan pemasukan dan pengeluaran kas secara sederhana secara syari`ah.

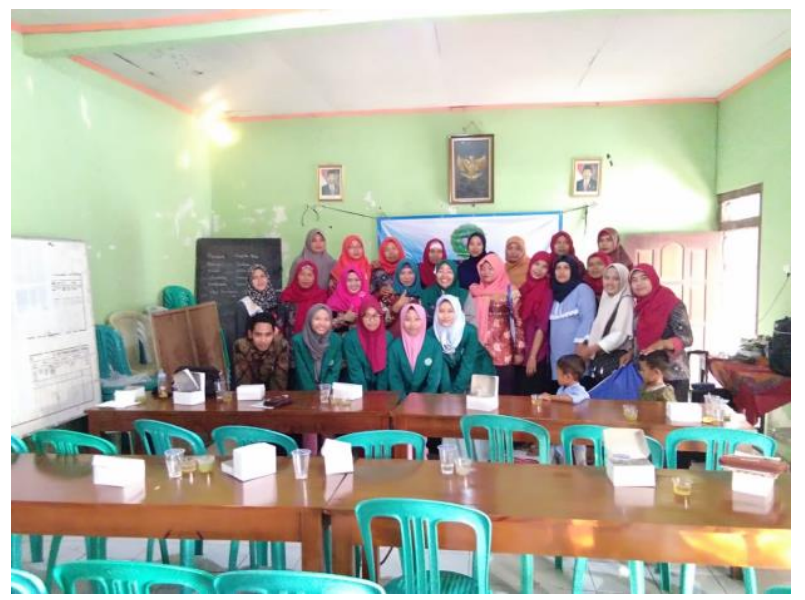

Gambar 1: Poto Bersama Masyarakat Desa Batu Kecamatan Karang Tengah Kabupaten Demak

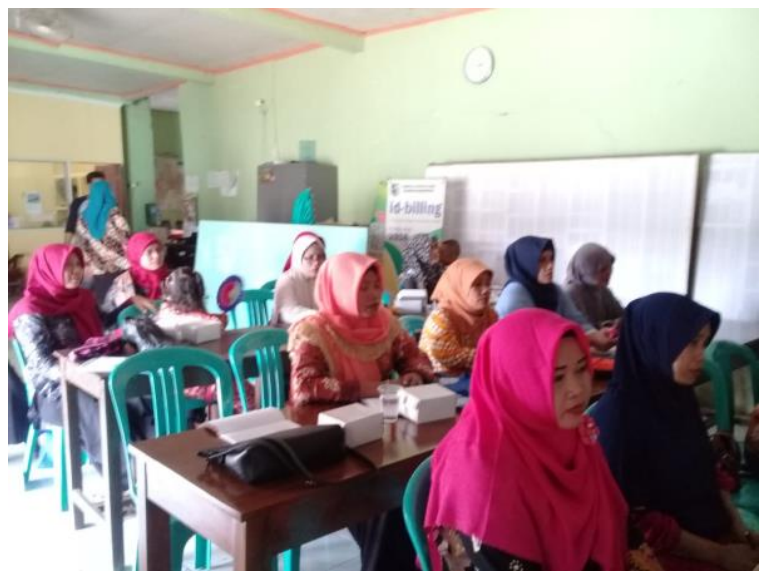

Gambar 2: Antusias Masyarakat untuk Mengikuti Pelatihan Pengelolaan Keuangan Secara Syariah 


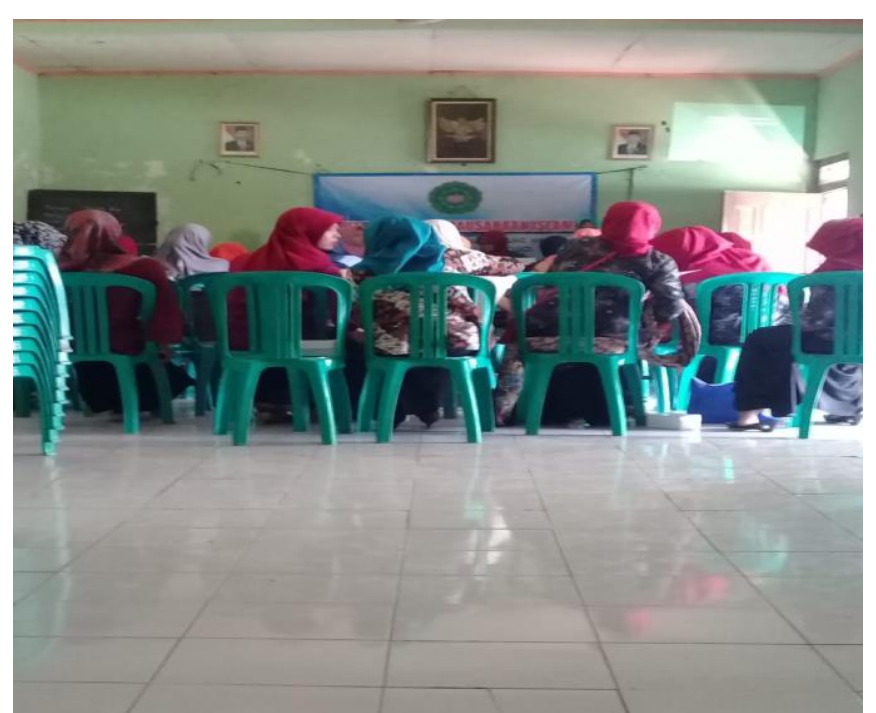

Gambar 3: Pemberian Materi Untuk Masyarakat Desa Batu Kecamatan Karang Tengah Kabupaten Demak

Aturan Penggunaan Keuangan dalam Keluarga, seorang kepala rumah tangga yang berpenghasilan ratusan juta rupiah bisa mengalami shock ketika menemukan uangnya tinggal Rp. 500.000 sebelum akhir bulan. Karena itu aturan penggunaan keuangan dalam keluarga harus dapat dipahami dan diterapkan dengan baik jika tidak ingin shock sebelum akhir bulan. Jika mengacu pada kerangka pengelolaan keuangan dalam Islam yaitu untuk mencapai falah dan tahapan untuk mencapai falah maka pemanfaatan pendapatan harus mencakup tujuan kebahagiaan hidup di dunia dan kesuksesan hidup di akhirat. Pernyataan di atas mensiratkan bahwa masalah keuangan keluarga bukan terletak pada penghasilan yang kurang, tapi kebiasaan yang salah dalam mengelola uang.

Jika demikian adanya, maka secara sederhana menurut Ligwina hal-hal yang harus diperhatikan dalam menggunakan keuangan dalam keluarga, yaitu: (1) memahami portofolio keuangan keluarga, (2) menyusun rencana keuangan atau anggaran, (3) memikirkan secara seksama pengertian antara butuh dan ingin, (4) menghindan hutang, (5) meminimalkan belanja konsumtif, (6) menetapkan tujuan atau cita-cita finansial, (7) menabung, dan (8) berinvestasi. Pertama, memahami portfolio keuangan keluarga. Setiap kepala rumah tangga harus tahu isi tabungannya, jumlah tagihan listrik, telepon, servis mobil, belanja, biaya periksa dokter dan lainnya. Demikian juga harus tahu berapa hutang kartu kredit, pinjaman bank atau cicilan rumah dan mobil. Kedua, menyusun rencana keuangan atau anggaran. Rencana keuangan yang realistis membantu setiap keluarga bersikap obyektif soal pengeluaran yang berlebihan. Tidak perlu terlalu ideal, sehingga lupa kebutuhan diri sendiri. Namun, tak ada salahnya memasukkan kebutuhan pergi ke salon, spa atau clubbing, yang penting harus dianggarkan jumlah yang realistis dan patuh dengan anggaran tersebut.

Ketiga, memikirkan lebih seksama pengertian antara "butuh" dan "ingin". Orang sering membelanjakan uang untuk hal yang tak terlalu penting atau hanya didorong keinginan, bukan kebutuhan. Karena itu, kita harus membuat daftar berupa tabel yang terdiri dari kolom untuk item belanja, kebutuhan dan keinginan. Setelah mengisi kolom item belanja, kolom "kebutuhan" dan "keinginan" harus diisi dengan tanda cek (V). Dari sini dapat dipertimbangkan dengan lebih matang tentang benda atau hal yang perlu dibeli/penuhi atau tidak. Keempat, menghindari hutang. Godaan untuk hidup konsumtif semakin besar. Namun bukan berarti dengan mudah kita bisa membeli berbagai benda secara kredit. Karena itu, kita harus bisa menumbuhkan kebiasaan keuangan yang sehat dimulai dari yang sederhana, seperti tak memiliki hutang konsumtif. Kelima, meminimalkan belanja konsumtif. Bertemu teman lama untuk bertukar pikiran di kafe terkadang memang perlu, tapi tak berarti kita harus melakukannya di setiap Jumat sore. Kita bisa gunakan pengeluaran ini untuk menabung atau memenuhi kebutuhan lain. Keenam, menetapkan tujuan atau cita-cita finansial. Kita harus bisa menyusun target keuangan yang ingin dicapai secara berkala, 
bersama pasangan. Dengan demikian, tujuan spesifik, realistis, terukur dan dalam kurun waktu tertentu harus ditetapkan. Tujuan ini membantu kita lebih fokus merancang keuangan.

Misalnya, bercita-cita punya dana pendidikan prasekolah berstandar internasional dan sebagainya. Ketujuh, menabung. Kita harus bisa mengubah kebiasaan dan pola pikir segera setelah menerima gaji, menyisihkan sebagian untuk tabungan dalam jumlah yang telah direncanakan sesuai tujuan atau cita-cita finansial keluarga. Sebaiknya, setiap keluarga memiliki rekening terpisah untuk tabungan dan kebutuhan sehari-hari. Kedelapan, berinvestasi. Tentu kita tidak akan puas dengan hanya menunggu tabungan menjadi banyak, karena setiap keluarga memiliki cita-cita yang sangat banyak. Inilah saat yang tepat untuk memikirkan investasi. Kini bentuknya macam-macam. Tak perlu khawatir akan risiko investasi, kita hanya perlu belajar pada ahlinya. Karena itu, kondisi keuangan keluarga harus dikonsultasikan dengan ahli keuangan yang handal.

\section{KESIMPULAN}

Setelah diberikan pelatihan pengelolaan keuangan rumah tangga secara syariah dengan materi yang berjudul Pengelolaan Keuangan Keluarga dan Bagaimana Agar Bisa Terbentuknya Sebuah Keluarga Yang Sakinah Desa Batu Kecamatan Karang Tengah Kabupaten Demak dapat tercapai menjadi perwujudan keluarga sakinah melalui pengelolaan keuangan rumah tangga secara syari ah maka diharapkan mitra dapat meningkatkan kesadaran masyarakat tentang pentingnya menentukan skala proritas dalam pengelolaan keuangan rumah tanggga secara syari ah, perwujudan keluarga sakinah melalui pengelolaan keuangan rumah tangga secara syari ah maka diharapkan mitra dapatmemahami tentang pentingnya menjaga keseimbangan antara pemasukan dan pengeluaran rumah tangga secara syari ah, perwujudan keluarga sakinah melalui pengelolaan keuangan rumah tangga secara syari ah maka diharapkan mitra dapat memahami pengetahuan tentang perlu perencanaan yang matang setiap pengeluaran baik yang rutin seperti belanja bebutuhan rumah tangga sehari-hari dan pengeluran non rutin seperti pembelian peralatan rumah tangga, liburan dan lain-lain, dan perwujudan keluarga sakinah melalui pengelolaan keuangan rumah tangga secara syari ah maka diharapkan mitra dapat memahami pelatihan tentang pencatatan pemasukan dan pengeluaran kas secara sederhana secara syari ah

\section{DAFTAR PUSTAKA}

Baron, R. A. dan Donn Byrne, Psikologi Sosial, Terj., Jakarta: Erlangga, 2003.

Clayton, Richard R, The Family, Mariage and Social Change, USA:Lawrence Elbraum Press, 2003.

Departemen Agama RI, Al-Qur'an dan Terjemahnya, Bandung: CV Penerbit Diponegoro, 2003. Al-Ghazali, Ihya Ulumuddin, Juz III, Beirut: Dar al-Khair, 1999.

Japari, Antony, "Konsep Perencanaan Keuangan Keluarga", Dokumen Internal, Financial Planner Assosiasi Indonesia, 23 Agustus 2012.

Khaldun, Ibnu, al-Muqaddimah, Beirut: Dar al-Fikr, 1988.

Khan, Muhammad Akram, An Introduction to Islamic Economics, IslamabadPakistan: International Institue of Islamic Thought and Institute of Policy Studies, 1994.

Liqwina, "Cara Sederhana Mengelola Keuangan Keluarga", Dokumen Internal, Financial Planner Assosiasi Indonesia, 23 Agustus 2012.

Mandell, Lewis and Linda Schemid Klein, "The Impact of Financial Literacy Education on Subsequent Financial Behavior", Journal of Financial Counseling and Planning, Volume 20 Issue 12009.

Minuchin, S., Families and Family Therapy, Cambridge, MA: Harvard University Press, 1999. 